www.volsu.ru

DOI: http://doi.org/10.15688/nav.jvolsu.2017.1.2

UDC 902(470.621.67)

LBC 63.4(2)(235.7)

\title{
COSSACK'S DUGOUTS IN THE BURIAL MOUND ON THE KUBAN RIVER RIGHT BANK (BASED ON SECURITY EXCAVATIONS IN 2013)
}

\author{
Yuriy Yu. Kargin \\ Arkheologicheskaya ekspeditsiya Ltd, Rostov-on-Don Region, Russian Federation
}

\begin{abstract}
The article is devoted to the publication of the late Middle Ages - Modern Times monuments of the burial mound, located on the Kuban river right bank. There is a description of the six similar dugouts with the stoves and a few pits located around hypothetical center.

Small dugouts were designed for two people and were used for a short time, and the minor concentration of mass archaeological material (bones and pottery) evidences to it. Each dugout had a stove located in the entrance's opposite side of rectangular trench over its floor. All stoves had a domical vault without chimney, a narrow furnace opening, calcined furnace walls and a flat smeared with clay bottom. There also was a narrow slot below the stove mouth and further to the entrance. The ditch in the center of the dugout's floor was filled with coal and ashes.

Despite the dominance of "Crimean" group of glazed and non-glazed pottery, the pieces of the fish and pig bones give us the idea about no Muslim worship of the local residents. A flint stone and the lead spherical bullet are often interpreted as common findings in the Russian colonist's settlements dated by the $17^{\text {th }}-18^{\text {th }}$ centuries. Than the dugouts were often used as the seasonal Cossack's dwellings for fishing, one of their main avocations. The construction features of the dugouts have the ethnographical analogies in the Don region. A small settlement with the circular layout was named "kuren".

The analysis of the excavations' results let us identify the peculiarities of the Cossacks' adaptation on the colonizing territories of the Kuban region and trace the traditional house-building features in the end of the $17^{\text {th }}$ and at the beginning of the $18^{\text {th }}$ centuries.
\end{abstract}

Key words: Cossacks, Crimean Khanate, a burial mound, a dugout, a pit, a stove, a ditch, kuren.

Citation. Kargin Yu.Yu., 2017. Cossack's Dugouts in the Burial Mound on the Kuban River Right Bank (Based on Security Excavations in 2013). The Lower Volga Archaeological Bulletin, vol. 16, no. 1, pp. 19-37. (in Russian).

УДК 902(470.621.67)

ББК 63.4(2)(235.7)

\section{КАЗАЧЬИ ЗЕМЛЯНКИ В КУРГАНЕ НА ПРАВОБЕРЕЖЬЕ КУБАНИ (ПО МАТЕРИАЛАМ ОХРАННЫХ РАСКОПОК В 2013 г.)}

\author{
Юрий Юрьевич Каргин \\ ООО «Археологическая экспедиция», Ростовская область, Российская Федерация
}

\footnotetext{
Аннотация. Статья посвящена публикации памятников позднего Средневековья - Нового времени из кургана на правобережье Кубани. Дано описание 6 расположенных вокруг условного центра однотипных землянок с печами, а также нескольких ям.

Небольшие землянки были рассчитаны на пару человек и использовались непродолжительное время, о чем свидетельствует слабая их насыщенность массовым материалом (костями и керамикой). В каждой из них в противоположной от входа стенке прямоугольного котлована, над его полом, была вырыта печь небольшого размера. Печь имела куполообразный свод без дымохода, узкое топочное отверстие, прокаленные стенки и обмазанное глиной ровное дно. Чуть ниже от печи ко входу следовала узкая, заполненная углем и золой канава, прорезавшая пол котлована примерно в центре.

Несмотря на преобладание поливной и неполивной керамики «крымской» группы, обломки костей рыбы и свиньи свидетельствуют о немусульманском вероисповедании жителей землянок. Кресальный кре-
} 
Yu.Yu. Kargin. Cossack's Dugouts in the Burial Mound on the Kuban River Right

мень и свинцовая сферическая пуля являются характерными находками на поселениях русских колонистов XVII-XVIII веков. Известно, что в это время в казачьей среде земляные постройки часто использовались в качестве сезонных жилищ, а рыбный промысел был одним из основных занятий. Общие конструктивные особенности землянок находят этнографические аналогии на Дону. Небольшой поселок с круговой планировкой на случай обороны назывался «курень».

Таким образом, материалы раскопок позволяют определить специфику процесса адаптации казаков на осваиваемых территориях Кубани и проследить черты их традиционного домостроения на рубеже XVIIXVIII веков.

Ключевые слова: казаки, Крымское ханство, курган, землянка, яма, печь, котлован, курень.

Цитирование. Каргин Ю. Ю., 2017. Казачьи землянки в кургане на правобережье Кубани (по материалам охранных раскопок в 2013 г.) // Нижневолжский археологический вестник. Т. 16, № 1. С. 19-37.

В 2013 г. экспедицией ООО «Археологическое общество Кубани» под руководством А.А. Козорезова и Ю.Ю. Каргина проводились охранные раскопки курганной группы № 46 в окрестностях хут. Ханьков Славянского района Краснодарского края в зоне проектируемого строительства трассы газопровода-отвода и вдольтрассовой линии электропередач ${ }^{1}$. Курганы были расположены на краю пахотного поля, на высоком правом берегу р. Кубань, а именно - на северо-восточном склоне Анастасиевской возвышенности, к северу от окраины хут. Ханьков (рис. 1,1-2).

Рельеф местности здесь достаточно спокойный. Берег Кубани чуть возвышен над окружающей местностью и плавно переходит в Анастасиевскую возвышенность, на которой расположены многочисленные курганы и курганные группы. С возвышенности хорошо просматривается низкий левый берег р. Кубань, на горизонте смыкающийся с предгорьями Большого Кавказского хребта.

Курганная группа № 46 состояла из трех курганов (рис. 1,3), раскопки насыпей № 2 и 3 осуществлялись на снос при помощи бульдозера. Курган № 3 оказался всхолмлением, образовавшимся при обустройстве газозамерной скважины. Отчетливо выделявшийся на местности курган № 2 сегментовидной формы, высотой 0,5 м и диаметром 35 м, оказался довольно интересным памятником, в котором, помимо трех погребений раннего железного века и одного более позднего, было исследовано 6 компактно расположенных землянок с небольшими печами и близлежащими ямами, датируемыми концом XVII началом XVIII века.

\section{Стратиграфия}

Для стратиграфических наблюдений были оставлены 3 бровки, ориентированные по линии 3-В (рис. 2). Под пахотным слоем, мощность которого достигала от 0,2 м в центре кургана до 0,4-0,5 м у его границы, зафиксирована единственная насыпь, представленная серо-коричневым очень плотным суглинком максимальной мощностью 0,8 м у условного центра (R0). Под насыпью находился слой погребенной почвы - серо-коричневый суглинок с мелкими органическими вкраплениями фосфатов белого цвета. Его максимальная мощность достигала 0,2 м у R0. Под ним на глубине 1,2 м от R0 зафиксирован материк - плотный желто-коричневый суглинок.

В середине центральной бровки отмечался пробой грабительской ямы 10 с почти вертикальными стенками, разрушившей центральное погребение. К востоку и западу от него были заметны неглубокие, но протяженные пробои с прослойками угля и золы, относящиеся, как впоследствии выяснилось, к землянкам 4 и 5. Схожий пробой от землянки 6 отмечался и в северной бровке, к востоку от ее центра, а к западу, на уровне материка и погребенной почвы, зафиксирована печь 5, впущенная в насыпь сбоку. Зачистка уровня материка вблизи печи показала, что в северном направлении от нее продолжается крупная яма, оказавшаяся котлованом землянки 2.

\section{Особенности планиграфии, землянки с печами и ямы}

К сожалению, при разборе насыпи очертания котлованов землянок в большинстве случаев не были заметны из-за специфики 
грунта: пробои были выявлены на профилях стратиграфических бровок только после их зачистки, то есть на финальной стадии раскопок кургана, когда от землянок уже почти ничего не осталось. Последнее выяснилось, когда при зачистке уровня материка была зафиксирована, а затем исследована землянка 2. Тогда же было установлено, что протяженные ямы 2, 3, 4, 7 и 9 с золистым заполнением, выявленные в материке, являются заглубленными коридорами землянок, а печи $1-4$, исследованные при разборе насыпи, составляют с ними единое целое. Разница высот между дном печи и дном коридора во всех случаях составляет 0,5-0,6 м, угли и зола выгребались из печи в этот коридор. В отличие от земляночных котлованов, печи выделялись хорошо заметным контурным прокалом красно-коричневого цвета с золистым заполнением. Таким образом, протяженные ямы и печи позволяют установить месторасположение землянок и отчасти их размеры.

У исследованных печей, несмотря на различия в форме и ориентировке топочных отверстий, хорошо заметны общие конструктивные особенности. Все они небольшого размеpa, стенки прокалены до оранжево-красного кирпичного цвета на 3-4 см. Дно обмазано глиной, вследствие обжига приобрело серо-коричневый с красноватым оттенком цвет и потрескалось. Заполнение представлено темным серокоричневым суглинком с примесью золы и мелких угольков. Находок в них не встречалось, за исключением правильно уложенных в обмазку четырех плоских кирпичей на дне печи 5 , а также двух фрагментов толстостенного горшка в печи 1. Свод практически у всех печей не сохранился. Лишь при исследовании печи 5, зафиксированной в стратиграфической бровке, удалось выяснить, что все печи выкапывались не сверху, а сбоку - в противоположной от входа стенке землянки, их свод был куполообразный, монолитный, без дымохода. Судя по всему, небольшие печи служили для отопления и выкуривания насекомых.

Землянка 1 (рис. 2, 3,4) обнаружена к северо-западу от условного центра кургана. Первоначально в насыпи кургана была выявлена печь $4 \mathrm{c}$ расходящимся от нее широким контуром котлована землянки. Она представляла собой подквадратную в плане яму
$0,9 \times 1$ м с зафиксированной глубиной около 0,15 м, с вертикальными стенками и зауженным топочным отверстием, обращенным на запад, в сторону котлована постройки. Дно печи было покрыто слоем обмазки, стены прокалены, заполнение - темно-коричневое, золистое, свод не прослеживался. Котлован землянки, длиной 2,8 м и шириной 3,4 м, имел прямоугольную с неровными краями форму, равномерно расширяясь в обе стороны от топочного отверстия печи. Его низ был зафиксирован на уровне дна печи. Заполнение котлована - темный серо-коричневый суглинок с примесью золы и мелких угольков. В дальнейшем при разборе насыпи в материке, под котлованом землянки, была обнаружена яма 4, являющаяся его продолжением. Яма продолговатой подпрямоугольной формы, с неровными краями, с размерами $4,8 \times 1$ м и глубиной до 0,18 м от уровня материка была ориентирована по линии В-3, чуть расширяясь в западном направлении. Дно ямы неровное, чуть западнее середины имеется 2 округлых заглубления, а в ее юго-западном крае - небольшое овальное заглубление. Заполнение ямы - темный серо-коричневый суглинок с примесью золы и мелких угольков, в нем найдено 35 костей животных и рыбы, а также 3 фрагмента печной обмазки серо-коричневого цвета. Разница высот между дном печи 4 и дном ямы 4 составила от 0,4 до 0,5 м. Начинаясь от печи, яма 4 была направлена на запад - ко входу, разделяя котлован узким коридором на 2 неодинаковые части и выходя за его пределы. По сравнению с северной частью, достигавшей 1,5 м в ширину, южная была заметно уже - от 0,5 до 1 м. Очевидно, что котлован землянки имел корытообразный профиль.

Землянка 2 (рис. 2, 4) была обнаружена на уровне материка в северо-западной части кургана, на краю его полы, и стала отправной точкой для понимания конструктивных особенностей прочих землянок. Первоначально в северной бровке была обнаружена печь 5 с размерами $1,2 \times 0,8$ м, которая, исходя из стратиграфии, была впущена в насыпь сбоку, со стороны котлована землянки. Ее топочное отверстие вытянутой подпрямоугольной формы ориентировано на СС3, стенки обожжены до красно-коричневого цвета, сужаются кверху, образуя цельный куполообразный свод высо- 
той до 0,5 м без дымохода. Заполнение печи темно-коричневое, золистое. Дно было покрыто слоем потрескавшейся обмазки, стены прокалены. В глубине печи, в 0,5 м от топочного отверстия, в дно вкопаны 4 плоских прямоугольных кирпича с размерами $25 \times 15 \times 5$ см. Кирпичи низкого качества были расположены в правильном порядке - в 2 ряда по 2 штуки друг за другом, ориентированы длинной стороной по оси печи. Котлован землянки расширялся в обе стороны от топочного отверстия, его ширина достигала 3 м, дно находилось на 0,1 м ниже дна печи, от которой в сторону входа, на ССВ, следовал заглубленный на 0,45 м в дно котлована узкий коридор длиной 6,3 м. Коридор делил дно котлована на 2 одинаковые выступающие части с размерами $2,8 \times 0,8$ м, напоминающие нары, и выходил за его пределы, образуя там продолговатый тамбур с двумя деформировавшимися ступенями. Таким образом, профиль котлована в поперечнике имел корытообразную форму с вертикальными стенками. Кроме того, у коридора с западной стороны имелось округлое боковое углубление длиной 1,6 м и шириной 0,8 м, чуть более заглубленное в грунт, чем тамбур. Заполнение котлована - темный серо-коричневый суглинок с примесью золы и мелких угольков, сосредоточенных преимущественно в узком тамбуре. В котловане землянки обнаружен 21 фрагмент костей животных и 5 фрагментов керамики, а именно: фрагмент венчика красноглиняного неполивного кувшина «крымской» группы, ручка поливного кувшина «крымской» группы, 3 фрагмента стенок сероглиняного и светлоглиняных круговых сосудов.

Землянка 3 (рис. 2) обнаружена к ЮВ от условного центра кургана. Она представлена печью 1 , исследованной в насыпи, и ямой 9 , зафиксированной на уровне материка. Очертания котлована в насыпи проследить не удалось. Печь 1 (рис. 3,1 ) - грушевидная в плане яма $1 \times 0,7$ м с вертикальными стенками и обращенным на ВCВ зауженным топочным отверстием. Дно было покрыто слоем потрескавшейся обмазки, стены прокалены, свод не прослеживался. Зафиксированная глубина печи - 0,25 м, ее заполнение - темно-коричневое, золистое, с 2 фрагментами толстостенного сероглиняного горшка с коричневым за- калом поверхности. Ниже была обнаружена яма 9 (рис. 6,2) продолговатой подпрямоугольной формы 4,4 × 0,8 м с неровными закругленными краями, ориентированная по линии В-3. Западный край ямы вплотную примыкал к топочному отверстию, по отношению к дну печи она была заглублена на 0,58 м. В восточной части ямы имелось небольшое возвышение, напоминавшее ступеньку перед входом, находившимся, судя по всему, с восточной стороны. Дно ямы глубиной до 0,35 м от уровня материка неровное, заполнение - темный серокоричневый суглинок с примесью золы и мелких угольков, локализованных преимущественно в западной части ямы, где они залегали послойно.

Землянка 4 (рис. 2) обнаружена к ВСВ от условного центра кургана. Она представлена печью 2 , исследованной в насыпи, ямой 2 , зафиксированной на уровне материка, а также пробоем в северном фасе центральной бровки. Печь 2 (рис. 3,2) - подквадратная в плане яма с размерами $0,7 \times 0,8$ м и глубиной до 0,15 м от уровня материка, с расширяющимися книзу стенками и обращенным на восток чуть зауженным топочным отверстием, над которым был зафиксирован участок свода высотой до 0,28 м с аркообразным профилем. Дно покрыто слоем потрескавшейся обмазки, стены прокалены, заполнение - темно-коричневое, с большим содержанием мелких угольков и золы. Ниже была обнаружена яма 2 (рис. 5,5) продолговатой подпрямоугольной формы с неровными краями, с размерами $4,5 \times 0,6$ м, ориентированная по линии $3-\mathrm{B}, \mathrm{c}$ небольшим прямоугольным расширением в западной части. Западный край ямы был зафиксирован в 0,5 м восточнее топочного отверстия печи, по отношению к дну которой она была заглублена на 0,57 м. Дно ямы неровное, заполнение - темный серо-коричневый суглинок с примесью золы и мелких угольков, наибольшая концентрация которых отмечалась в западной части, вблизи печи. В заполнении, помимо мелких неопределяемых фрагментированных костей, найдено 6 более крупных фрагментов костей животных и рыбы, 3 фрагмента стенок красноглиняных круговых сосудов с примесью песка и слюды, фрагмент ручки красноглиняного сосуда, 2 фрагмента стенок светлоглиняных сосудов с внешней по- 
верхностью красного цвета, на одном из которых имелось небольшое округлое отверстие диаметром 0,4 см. Отдельного внимания заслуживает фрагмент полированного орнаментированного изделия из клыка кабана (?). В северном фасе центральной бровки, напротив ямы, был зафиксирован пробой шириной 2,8 м (рис. 2), разница глубины его дна и дна ямы составляла от 0,6 до 0,7 м - как разница между глубинами дна котлована и пересекающей его канавы у прочих землянок.

Землянка 5 (рис. 2) обнаружена к Ю3 от условного центра кургана, в непосредственной близости от него. Она представлена печью 3, исследованной в насыпи, ямой 7, зафиксированной на уровне материка, а также пробоем в южном фасе центральной бровки. Печь 3 (рис. 3,3) - грушевидная в плане яма $1,3 \times 0,9$ м с вертикальными стенками и обращенным на $3 Ю 3$ зауженным топочным отверстием. Дно было покрыто слоем потрескавшейся обмазки, стены прокалены, свод не прослеживался. Зафиксированная глубина печи - 0,3 м, ее заполнение - темно-коричневое, золистое. Ниже была обнаружена яма 7 (рис. 6,1) продолговатой подпрямоугольной формы 4,8 × 0,8 м с неровными и закругленными краями, ориентированная по линии ВСВ-ЗЮЗ, с неболышим овальным расширением в восточной части, заглубленным на 0,12 м по отношению ко дну ямы. Этим расширением яма вплотную примыкала к топочному отверстию. По отношению к дну печи яма была заглублена на 0,5 м, а ее расширение - на 0,62 м. Дно - неровное, глубиной до 0,3 м от уровня материка, заполнение темный серо-коричневый суглинок с примесью золы и мелких угольков, в котором также было найдено 14 фрагментов костей животных и рыбы, а также свинцовая сферическая пуля. Судя по расположению ямы, вход в землянку находился с ее западного конца. В южном фасе центральной бровки, напротив ямы, был зафиксирован пробой шириной около 3,5 м (рис. 2), разница глубины его дна и дна ямы составляла около 0,4 м - почти как разница между глубинами дна котлована и пересекающей его канавы у прочих землянок.

Землянка 6 (рис. 2, 5,4) сохранилась хуже всего: от нее осталась лишь узкая протяженная яма 3 и пробой в южном фасе северной бровки. Яма была зафиксирована на уровне материка, к СВ от условного центра кургана. Она канавообразной формы с неровными краями, с размерами 3,6 × 0,4 м и неровным дном глубиной до 0,2 м от уровня материка, ориентирована по линии ЗСЗ-ВЮВ, ее восточная часть завершается прямоугольной камерой $0,9 \times 0,8$ м. Заполнение ямы - темный серо-коричневый суглинок с обильной примесью золы, мелких угольков и мелких фрагментов костей животных. Наибольшая концентрация золы и углей встречена в прямоугольной камере. К западу от ямы в насыпи был зафиксирован прокал неясной конфигурации, который, судя по всему, являлся остатками печи. К сожалению, он практически не сохранился, но, тем не менее, указывает на расположение входа в землянку с восточной стороны. В южном фасе северной бровки, напротив ямы, был зафиксирован пробой шириной 2,8 м (рис. 2), разница глубины его дна и дна ямы составляла около 0,6 м - как разница между глубинами дна котлована и пересекающей его канавы у прочих землянок.

Кроме землянок, в кургане обнаружено 4 ямы различной формы и назначения. Находки позволяют отнести ямы 1, 5 и 8 к XVIII в., датировка ямы 6 неясна.

Яма 1 (рис. 5,1) округлой в плане формы диаметром до 1 м и зафиксированной глубиной около 0,1 м обнаружена в насыпи кургана, к северу от его условного центра и в центре пространства, образовавшегося между землянками. Заполнение ямы - темный серо-коричневый суглинок с примесью золы, мелких угольков, а также неопределяемых очень мелких фрагментов костей животных и рыбы. Судя по всему, яма использовалась как открытый костер, хотя прокал не зафиксирован.

Яма 5 (рис. 5,3) прямоугольной с округленными краями формы, с размерами 1,9 × 1 м и зафиксированной глубиной около 0,4 м была ориентирована длинной стороной по линии ВСВ-ЗЮЗ. Она обнаружена к западу от землянки 2 и оказалась наиболее насыщена находками. Дно ямы ровное, стенки вертикальные, заполнение - темный серо-коричневый суглинок с примесью золы и мелких угольков. В заполнении найдено 53 фрагмента костей животных и рыб, 2 фрагмента печной обмазки серо-коричневого цвета, 7 фрагментов керамики, фрагмент тонкой бронзовой 
пряжки (?) со штампованным орнаментом и кресальный кремень. Очевидно, яма выполняла роль мусоросборника.

Яма 6 (рис. 5,2) квадратной формы, с размерами $0,45 \times 0,45$ м и зафиксированной глубиной около 0,3 м, с вертикальными стенками и небольшим плоским уступом, напоминающим ступеньку. Обнаружена в материке к югу от условного центра кургана и к западу от землянки 3. Заполнение ямы - темный серо-коричневый суглинок с сохранившимся остатком вкопанного деревянного столба, который встречался и выше в насыпи. По остаткам коры можно предположить, что дерево относилось к отделу хвойных. Прочих находок не обнаружено, назначение ямы неясно.

$\boldsymbol{Я} \boldsymbol{\text { ма }} 8$ (рис. 6,1) прямоугольной с закругленными краями формы, с размерами $1,05 \times 0,8$ м, с зафиксированной глубиной около 0,2 м от уровня материка, почти вертикальными стенками и неровным дном была ориентирована длинной стороной по линии СС3ЮЮВ. Она была обнаружена к югу от центра ямы 7 и, таким образом, находилась за пределами землянки 5 или в южной части ее котлована. Заполнение ямы - темный серо-коричневый суглинок с примесью золы и мелких угольков, в нем найдено 6 фрагментов костей животных, рыбы и птицы.

Таким образом, установлено, что 6 однотипных землянок, сооруженных в полах кургана, располагались компактно, фактически по кругу, будучи направленными выходами от условного центра, в котором находилась яма 1. Вблизи зафиксировано еще 3 ямы, одна из которых выполняла роль мусоросборника, а назначение двух других неясно.

\section{Находки}

Поселенческий культурный слой XVIII в. на кургане обнаружен не был, находки этого времени оказались единичными и встречались преимущественно в ямах и землянках.

Керамика XVIII в. представлена немногочисленными фрагментами стенок круговых сосудов серо-коричневого, красного и бежевого цвета, изредка с зеленой глазурью. Несколько фрагментов характерной керамики было обнаружено при разборе насыпи, единич- ные фрагменты встречались в заполнении землянки 2, печи 1, а также в ямах 2, 4 и 5. Всего было найдено 28 фрагментов, лишь 7 из них оказались профильными.

Из насыпи происходит фрагмент округленного бортика поливной красноглиняной чаши «крымской» группы (рис. 7,1), изготовленной на этапе РФК-7, по А.А. Бобринскому [Бобринский, 1978, с. 27]. На внешней поверхности бортика при вращении круга нанесено 2 умеренно широких неглубоких концентрических желобка. Чаша покрыта плотным слоем белого ангоба, по которому на всю внутреннюю поверхность и на внешний край бортика нанесен слой темно-зеленой глазури, образуя в одном месте подтек. В составе глины присутствует небольшое количество шамота и редкие известковые включения. Эта группа керамики подробно описана И.В. Волковым [Волков, 1992, с. 16-17; 2005, с. 483-484; Волков, Петерс, 2003, с. 251-252]. Такие чаши представляют собой небольшие открытые приземистые сосуды с кольцевым поддоном. В нашем случае наличие кольцевого поддона устанавливается гипотетически, исключительно по известным аналогиям.

Небольшая, овальная в сечении, изогнутая знаком вопроса ручка поливного кувшина «крымской» группы встречена в заполнении землянки 2 (рис. 7,2). Высота ручки - 10 см. Она покрыта светлым ангобом, а поверх него светло-зеленой облупившейся глазурью. У верхнего прилепа имеется характерное утолщение, а нижний прилеп снизу размазан.

Там же был встречен фрагмент горла красноглиняного неполивного кувшина «крымской» группы с отогнутым и чуть утолщенным краем венчика. Считается, что такие сосуды продолжают эволюционную линию средневековой керамики группы Восточного и Юго-Западного Крыма [Волков 1992, с. 15-16].

Особый интерес вызывает толстостенный сероглиняный горшок с коричневым закалом поверхности, фрагменты верхней и нижней частей которого были обнаружены в печи 1 (рис. 7,4). Край венца широкий и плоский, толщина стенок в верхней части достигает 2 см. Горшок округлобокий, венчик выделен двумя концентрическими, глубоко продавленными желобками. Реконструируемый диаметр венчика $-11,4$ см, дна -8 см, диаметр максималь- 
ного расширения тулова $-12,8$ см, высота 11 см. В примеси незначительное количество мелкого песка и талька. Судя по всему, он был изготовлен на этапе РФК-5-6 по А.А. Бобринскому [Бобринский, 1978, с. 27].

3 фрагмента венчика, стенки и придонные части такого же горшка были обнаружены в яме 5 (рис. 7,5). Судя по размерам, цвету и примесям, они могут оказаться даже его частями. К сожалению, прямых аналогий этому типу горшков в археологической литературе обнаружить не удалось.

Таким образом, керамика XVIII в. из землянок, печей и ям в основном относится к «крымской» группе, широко распространенной в то время на территории Северного Причерноморья и Приазовья.

Кости жсивотных и изделия из них. Важная информация получена по итогам анализа костных остатков животных из ям и землянок, проведенного В.В. Соломахой. Отмечена высокая сохранность этих материалов, а также отсутствие на них омытости и следов огня. Из 135 обнаруженных фрагментов 117 (86,7 \%) являются определимыми, их распределение в ямах и землянках представлено в таблице. В целом можно говорить о явном преобладании костей свиньи $(37,8 \%)$, осетровых и придонных видов рыб $(38,5 \%)$, существенно меньше встречено костей крупного рогатого скота $(8,9 \%)$ и всего несколько птицы (1,5\%). Оставшуюся долю (13,3\%) составляют неопределимые фрагменты костей крупных и средних млекопитающих. К сожалению, эта археозоологическая коллекция не может считаться представительной по объему выборки, так как она не превышает минимально допустимый объем в 400 единиц, согласно методике Е.Е. Антипиной [Антипина, 2004, с. 7-19]. Однако, несмотря на это, можно сделать некоторые наблюдения и выводы:

1. На костях зафиксированы следы искусственного воздействия человека, представленные раздробами, а на свиных позвонках - продольными разрубами, что говорит об использовании мяса этих животных в пищу.

2. Основной лов осетровых в Кубани в то время мог осуществляться почти круглогодично, за исключением июля и первой половины августа, а лов придонных видов рыб - с июня по октябрь [Данилевский, 1871, с. 29]. Поэтому по имеющимся находкам рыбу следует также считать важной частью мясного рациона группы населения, проживавшей в землянках у хут. Ханьков.

3. Преобладание мяса домашней свиньи и рыбы в мясном потреблении указывает на немусульманский характер этого населения.

Для сравнения можно привести археозоологическую коллекцию с поселения Волна-12 (аул Тереклыкой) на Таманском полуострове, относящегося к местному населению того же времени. Она демонстрирует принципиально иную картину: большинство обломков костей животных принадлежит крупному рогатому скоту и лошадям, остальные - мелкому рогатому скоту и курице, костей свиньи и рыбы не встречено [Белов, Лукьяшко, Раев, 2015, с. 26]. Таким образом, очевидно, что местное мусульманское население и группа людей, оставивших в кургане у хут. Ханьков свои землянки, занимали разные пищевые ниши.

Единственное на памятнике изделие из кости обнаружено в яме 2 - коридоре землянки 4 (рис. 7,8). Находка представлена фрагментом полированного предмета, изготовленного, по-видимому, из клыка кабана. Монолитное изделие имеет треугольную форму, а его профиль представляет собой прямоугольный треугольник. Боковые грани скошены в сторону задней, а на передней и нижней нанесен сложный прорезанный геометрический орнамент: на передней - в виде треугольного контура, в основании которого двумя линиями отчерчены 2 пояска симметричных зигзагов, на нижней - в виде трех разнонаправленных многоярусных треугольников в общей рамке. В центре просверлено круглое сквозное сужающееся от 0,2 до 0,4 см отверстие, по линии которого отломана вершина изделия. Ширина находки 3,7 см, толщина - 1,6 см, сохранившаяся высота $-1,8$ см. Аналогий ей не встречено.

Предметы быта представлены одним кресальным кремнем из заполнения ямы 5 (рис. 7,6). Это трапециевидный отщеп коричневого цвета с размерами $2,2 \times 2,5 \times 1,2 \mathrm{~cm}$, утолщенный в середине, со слегка приостренным краем и нанесенной по нему с двух сторон мелкой ретушью со следами сработанности. 
К предметам фурнитуры, вероятно, следует отнести фрагмент тонкой бронзовой рамчатой пряжки (?) с ажурным краем из заполнения ямы 5 (рис. 7,7). Внешняя поверхность изделия, ширина которого достигала 3,3 см, покрыта орнаментом из расположенных в шахматном порядке проштампованных мелких равнобедренных треугольников.

Боеприпасы представлены свинцовой сферической пулей диаметром 0,9 см, обнаруженной в заполнении ямы 7 - коридора землянки 5 (рис. 7,9). Согласно О.В. Двуреченскому, это стандартный боеприпас к самым распространенным типам ружей XVIIXVIII вв. - ручным пищалям [Двуреченский, 2005, с. 287].

Таким образом, археологические материалы немногочисленны и маловыразительны, но при этом свидетельствуют о единовременности сооружения и использования всех вышеописанных землянок с печами и ям.

$$
* * *
$$

По итогам раскопок определено, что в насыпи кургана раннего железного века было сооружено 6 небольших однотипных землянок с печами, которые располагались компактно вокруг условного центра, их входы обращены на восток и запад, и лишь у землянки 2 - на север. Небольшие по занимаемой площади сооружения были рассчитаны на пару человек и использовались непродолжительное время, о чем свидетельствует слабая их насыщенность массовым материалом (костями и керамикой). Очевидно, что яма 1 в центре пространства, образовавшегося между землянками, являлась кострищем, у которого могла происходить общая трапеза. Яма 5, по всей видимости, выполняла роль мусоросборника. Непонятным осталось лишь назначение ямы 8, а также ямы 6 с остатками столба.

Несмотря на малую численность, археологические материалы XVII-XVIII вв. из кургана у хут. Ханьков весьма информативны для определения этнической принадлежности данной группы населения. Так, несмотря на преобладание керамики «крымской» группы, обломки костей рыбы и животных, прежде всего свиньи, свидетельствуют о не- мусульманском вероисповедании этих людей. На это косвенно указывают кресальный кремень и свинцовая сферическая пуля - характерные находки на поселениях русских колонистов XVII-XVIII веков. Кроме того, известно, что рыбный промысел в XVIII в. был одним из основных занятий казаков повсеместно на территории их проживания [Куманцов, 2011, с. 112-127].

Аналогичная картина мясного потребления и похожие находки отмечались на исследованных в Прикубанье участках поселений казаков-некрасовцев: на поселении Белое Юго-Восточное, датированном в пределах начала 1740-х - конца 1770-х гг. [Каргин, 2016], а также на расположенном в непосредственной близости от кургана поселении Ханьков II начала 1710-х - конца 1730-х годов. К сожалению, на этих памятниках не было выявлено построек. Постройки полуземляночного и земляночного типа XVIII в. нам известны только на исследованном недавно поселении Волна-12 (аул Тереклыкой), принадлежавшем мусульманскому населению Таманского полуострова [Белов, Лукьяшко, Раев, 2015, с. 27-30]. Печь в обнаруженной здесь полуземлянке (объект 7) была похожей формы, размеров и, судя по всему, также была выкопана в стене. Однако ее расположение на уровне пола и отсутствие канавы свидетельствуют, скорее, об отоплении каминного типа. Имеются принципиальные различия и в планировке внутреннего пространства. В частности, лежанка расположена напротив камина, вход находится со стороны печи и вблизи нее, в центре котлована имеются ямы осевой линии столбов, на которую опиралась кровля. На этом же поселении была зафиксирована отапливаемая лежанка - кан, относившаяся, по мнению авторов раскопок, к наземному жилищу. Она представляла собой топочную яму с ведущим от нее канавообразным воздуховодом, выкопанным на том же уровне, а стены всей конструкции были выложены пахсовыми блоками и сырцовыми кирпичами. Таким образом, исследованные в кургане у хут. Ханьков землянки демонстрируют иные традиции домостроения, отличавшиеся от местных, в том числе по конструкции кровли и типу отопительной системы. 
Между поселениями Белое Юго-Восточное, Ханьков II и группой землянок в кургане у хут. Ханьков хорошо просматриваются не только археологические, но и исторические параллели. Известно, что в конце XVII - первой половине XVIII в. в Прикубанье единственной немусульманской группой населения были русскоязычные колонисты. Поначалу это были группы старообрядцев, в том числе и казаки, бежавшие после церковного раскола. В 1708 г., после подавления Булавинского восстания, сюда же со скарбом и семьями устремилась большая группа донских «верховых» казаков под предводительством Игната Некраса (Некрасова). Вскоре они перешли в подданство к крымским ханам и, будучи освобожденными от налогов, участвовали в военных походах и войнах на стороне Крымского ханства и Турции, а также выполняли роль провожатых в донские земли [Сень, 2002, с. 23-26]. Заручившись их поддержкой, казаки смогли осесть на правобережье Кубани и впоследствии сманивать сюда своих бывших земляков.

Для выявления исторических аналогий особенно полезна работа волгоградских исследователей В.В. Когитина и М.А. Рыбловой, которые, опираясь на письменные и этнографические источники, определяют землянки и полуземлянки в качестве наиболее раннего типа традиционного жилья донских казаков [Когитин, Рыблова, 1995].

В старинной казачьей песне, известной по материалам этнографической экспедиции Волгоградского государственного университета [МЭЭ ВолГУ, 1983, с. 73], есть слова:

Аи, ну, пойдемте-ка, братиы, на Куму-реку. $A u$,мы пороем там, братиы, себе ямушки, Аи, мы поделаем себе балаганушки.

Аи, ну построим себе, братиы, мыз землянушки.

Земляные постройки хорошо соответствовали особенностям казачьего военного быта: на время длительных походов такие жилища забрасывали или разрушали. Чтобы соорудить их вновь, не требовалось много строительных материалов и больших временных затрат. Известно, что в XVIII в. земляные постройки часто использовались в качестве сезонных жилищ. Небольшие временные поселения с расположением нескольких пост- роек по кругу на случай вынужденной обороны имели название «курень». В. Даль допускал двоякое происхождение этого слова: от «куриться» или от монгольского «куря» (кочевье) [Даль, 1981, с. 222].

Согласно архивным материалам, стены казачьих землянок были рублеными, плетневыми или земляными. К сожалению, в землянках на кургане у хут. Ханьков следы стен и крыши проследить не удалось. Однако конструктивные особенности котлована позволяют предположить, что узкая канава в его центре, а также соединяемые ею печь и выход представляют собой поземную систему отопления, характерную для «хаток об одну комнату». По этнографическим данным небольшая печка прямоугольной формы соединялась боровком (канавой) с дымоходом. Такая система отопления сооружалась только в земляных полах, поверх боровка обычно устраивались спальные места, а печь топили хворостом [МЭЭ ВолГУ, 1987, с. 46]. Этим «поземка» была похожа на татарские каны. Интересно, что в Подонье термин «лежанка» долгое время бытовал у казаков наряду с термином «подземка».

Исходя из рассмотренных выше археологических аналогий, этнографических и исторических параллелей, комплекс землянок на кургане у хут. Ханьков следует считать казачьим «куренем», относящимся к первоначальному этапу проникновения казаков на Кубань до основания ими крупных стационарных поселений, и датировать его концом XVII - первым десятилетием XVIII века.

Таким образом, материалы раскопок кургана у хут. Ханьков позволяют реконструировать малоизвестные аспекты казачьего быта позднего Средневековья - Нового времени, определить специфику процесса адаптации казаков на осваиваемых территориях и проследить черты традиционного домостроения. Особенности исследованного археологического объекта заставляют поднять вопрос о перспективности дальнейшего выявления подобных памятников в Прикубанье и Подонье. Очевидно, что курганы в местах расселения казачества следует рассматривать не только как погребальные сооружения, но и как потенциальные поселенческие объекты. 


\section{ИЛЛЮСТРАЦИИ}
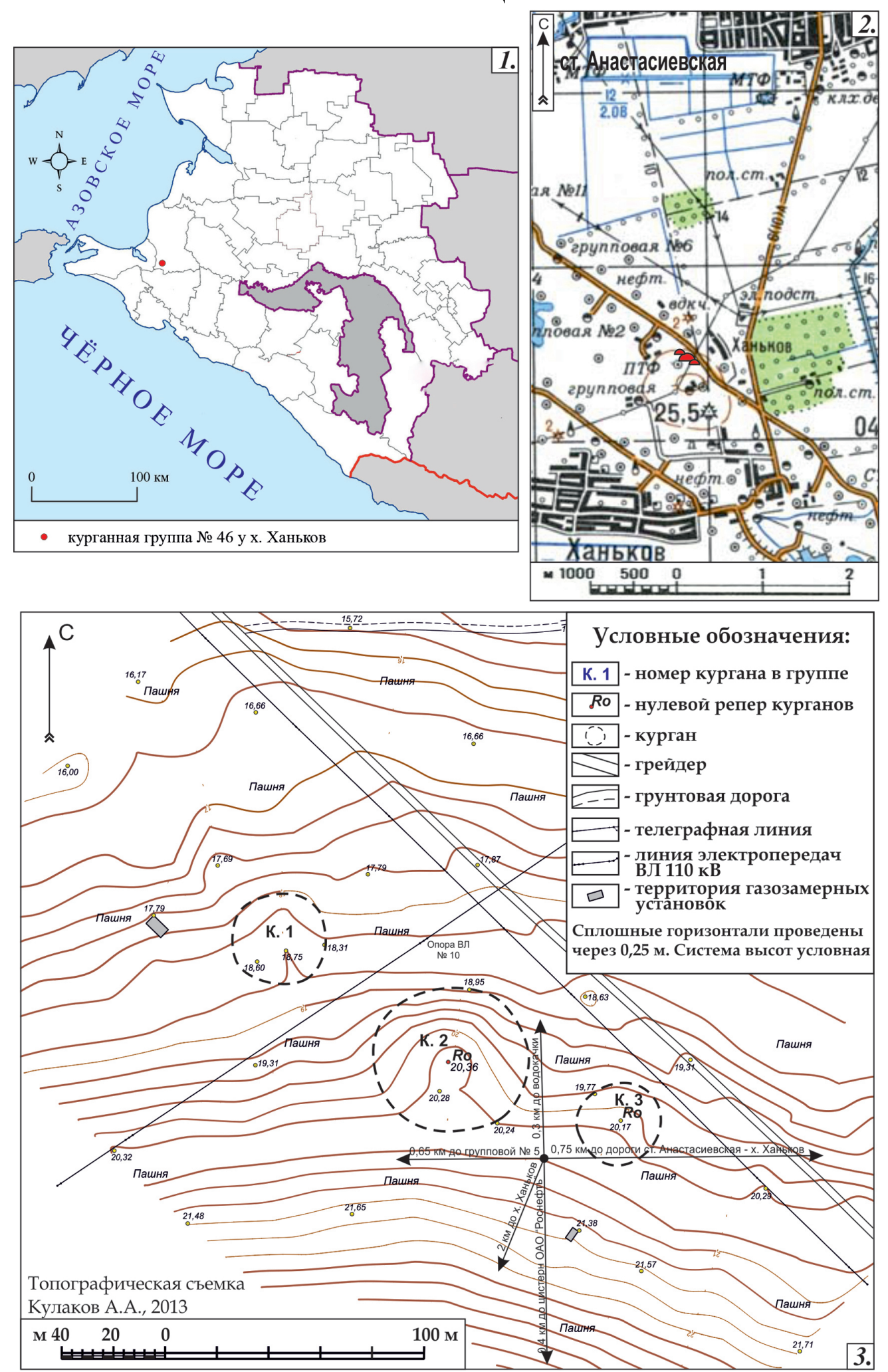

Рис. 1. Курганная группа № 46 у хут. Ханьков на топооснове:

1 - на карте-схеме Краснодарского края; 2 - на фрагменте карты Генштаба; 3 - топоплан А.А. Кулакова, 2013 г.

Fig. 1. Barrow group no. 46 near the Khankov village on topographic base: 1 - on the map-scheme of the Krasnodar region; 2 - on the fragment of General Staff map; 3 - the topographic plan drawn by A.A. Kulakov, 2013 


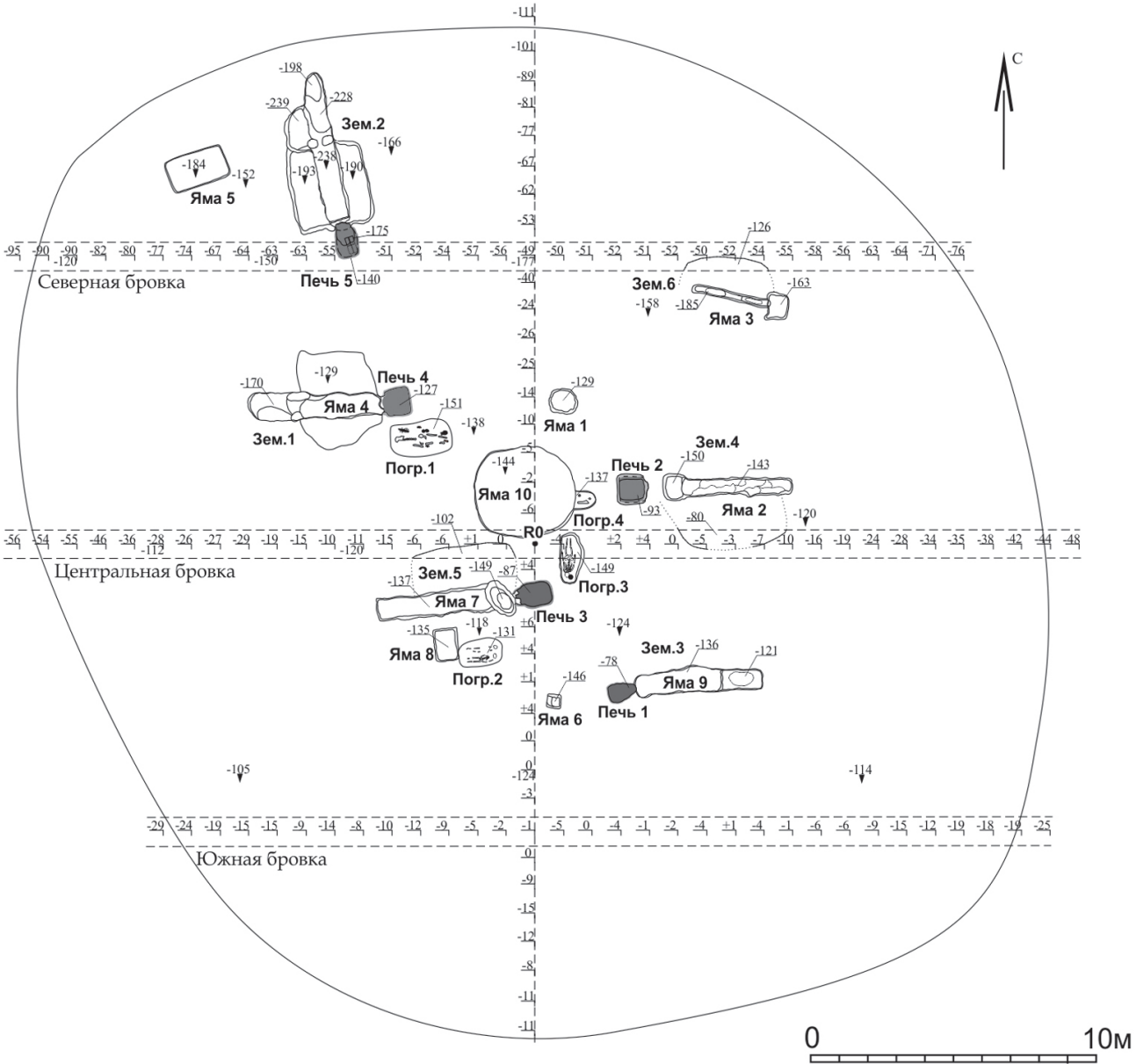

Северный фас северной бровки

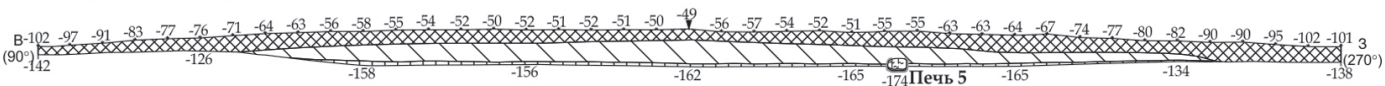

Южный фас северной бровки

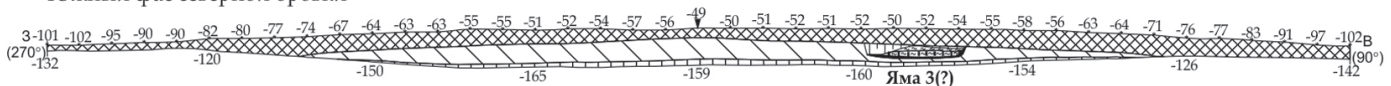

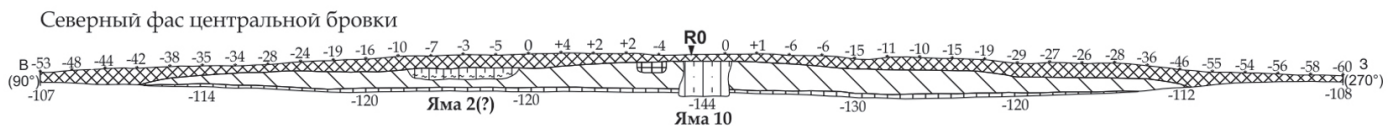

Южный фас центральной бровки

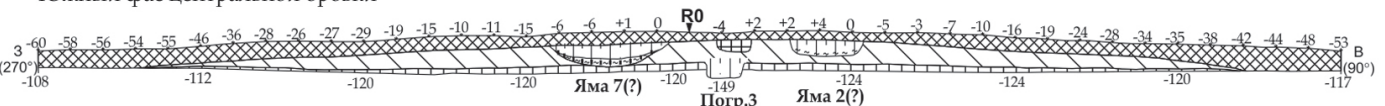

Северный фас южной бровки

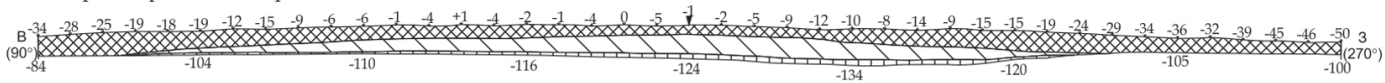

Южный фас южной бровки

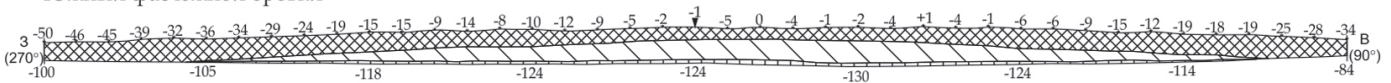

\section{Условные обозначения}

\begin{tabular}{lll} 
- пахотный слой & ' . ' & - древесные угольки \\
\hline$\square$ - насыпь 1 & - заполнение ям (рыхлый суглинок) \\
\hline$\square$ - слой погребённой почвы & - печь с обожжёнными глиняными стенками
\end{tabular}

Рис. 2. Курганная группа № 46 у хут. Ханьков. Курган 2. План и стратиграфия

Fig. 2. Barrow group no. 46 near the Khankov village. Barrow 2. The plan and stratigraphy 
Yu. Yu. Kargin. Cossack’s Dugouts in the Burial Mound on the Kuban River Right

\begin{tabular}{|c|c|c|c|c|}
\hline \multicolumn{5}{|c|}{ Условные обозначения для рисунков 3-6: } \\
\hline 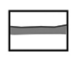 & - обожжённая стенка & ZZ - материк & $\sim \sim$ & - зола \\
\hline एव & - обожжённая глиняная обмазка & $\prod$ - слой погребённой почвы & ++ & - кости рыб \\
\hline$\Delta$ & - насыпь 1 & '. ' - древесные угольки & $x^{x}{ }^{x}$ & - кости животных \\
\hline
\end{tabular}



Рис. 3. Курганная группа № 46 у хут. Ханьков. Курган 2. Планы и профили печей и землянки 1 :

1 - печь $1 ; 2$ - печь $2 ; 3$ - печь $3 ; 4$ - печь 4 и яма 4 (землянка 1)

Fig. 3. Barrow group no. 46 near the Khankov village. Barrow 2. Plans and profiles of the stoves and dugout 1: 1 - stove $1 ; 2$ - stove $2 ; 3$ - stove $3 ; 4$ - stove 4 and pit 4 (dugout 1 ) 


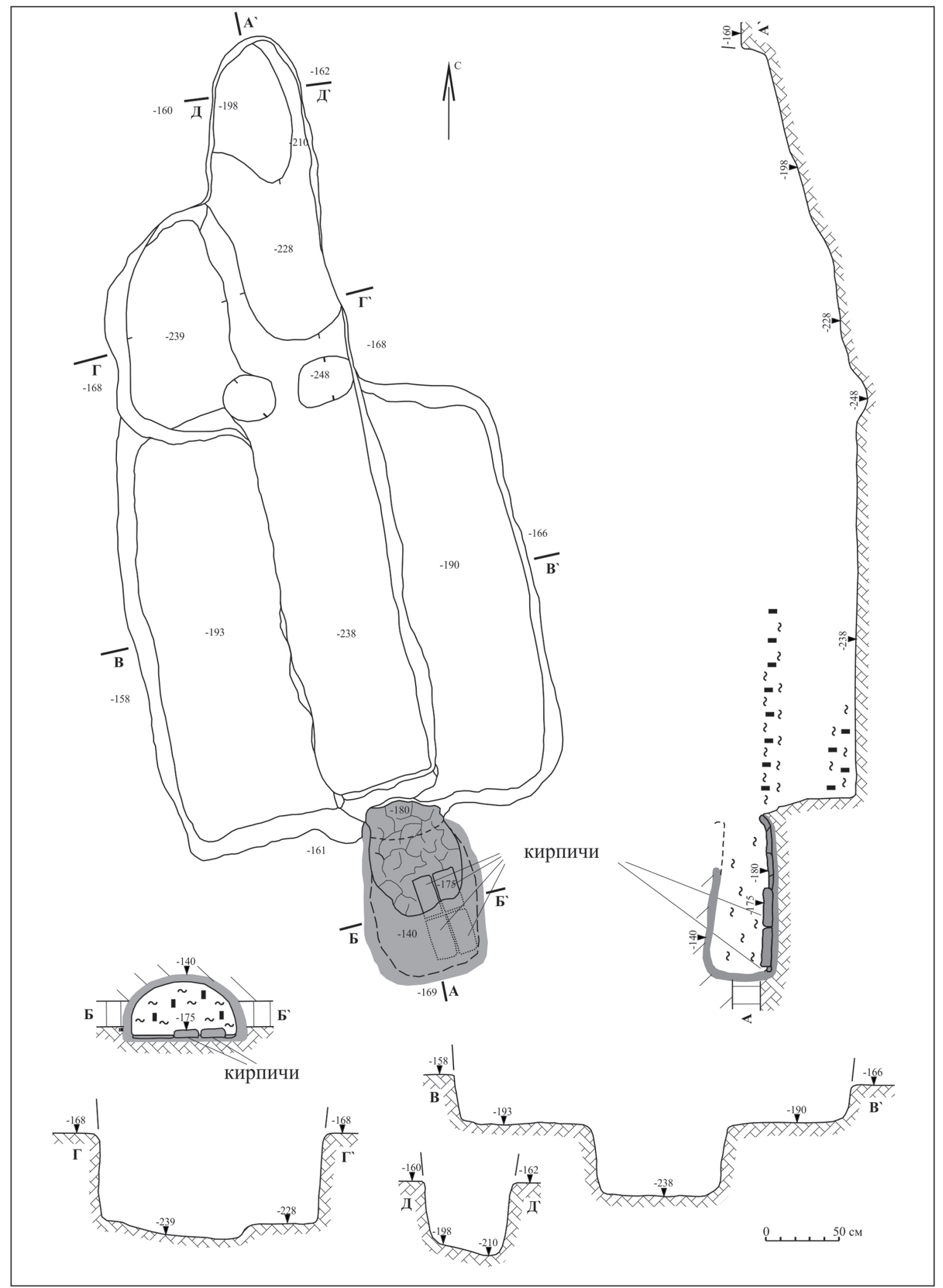

Рис. 4. Курганная группа № 46 у хут. Ханьков. Курган 2. План и профили землянки 2 и печи 5

Fig. 4. Barrow group no. 46 near the Khankov village. Barrow 2.

The plan and profiles of the dugout 2 and stove 5 
Yu.Yu. Kargin. Cossack's Dugouts in the Burial Mound on the Kuban River Right

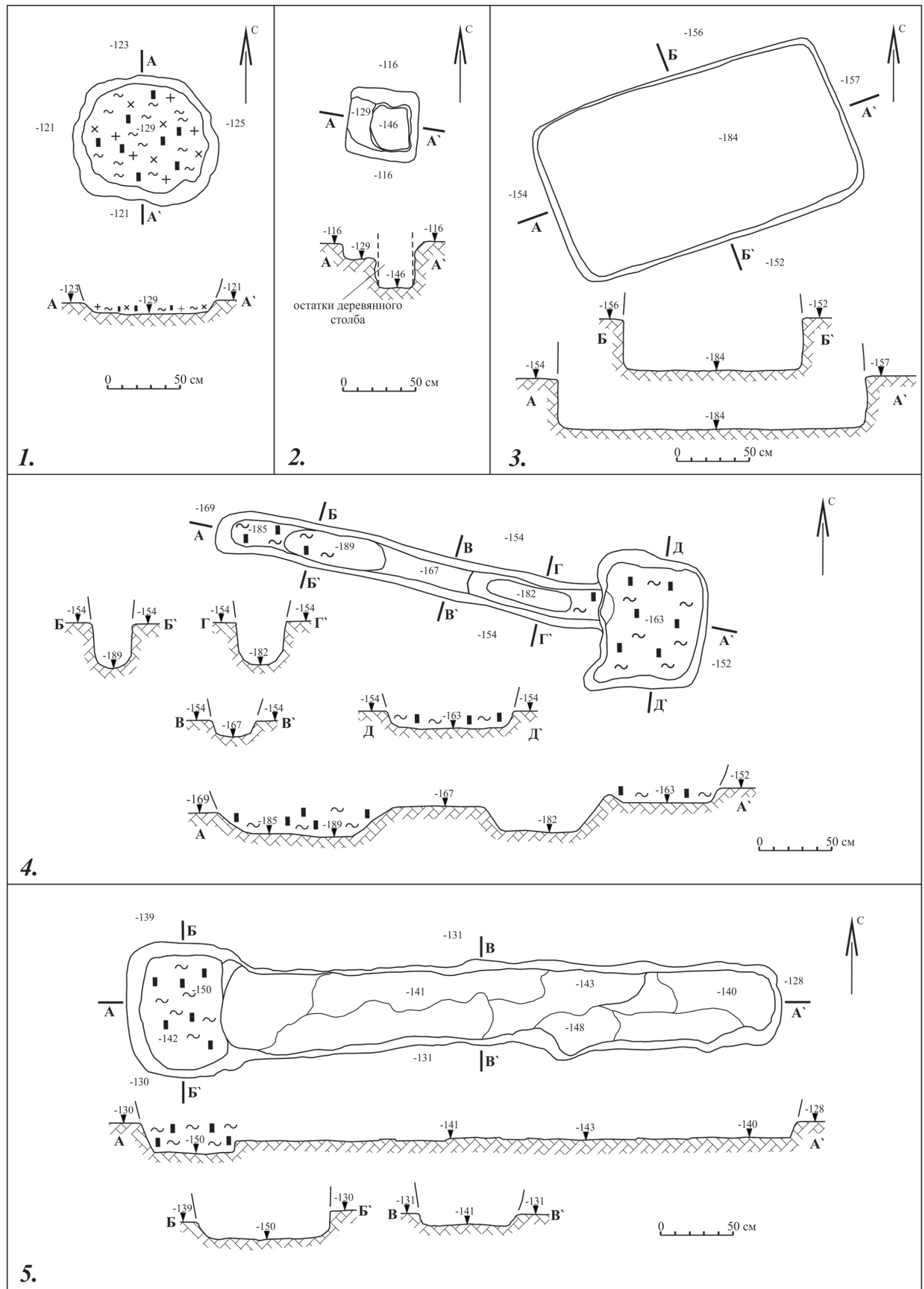

Рис. 5. Курганная группа № 46 у хут. Ханьков. Курган 2:

1 - яма $1 ; 2$ - яма $6 ; 3$ - яма $5 ; 4$ - яма $3 ; 5$ - яма 2

Fig. 5. Barrow group no. 46 near the Khankov village. Barrow 2:

1 - pit $1 ; 2$ - pit $6 ; 3$ - pit $5 ; 4$ - pit $3 ; 5$ - pit 2 



1.
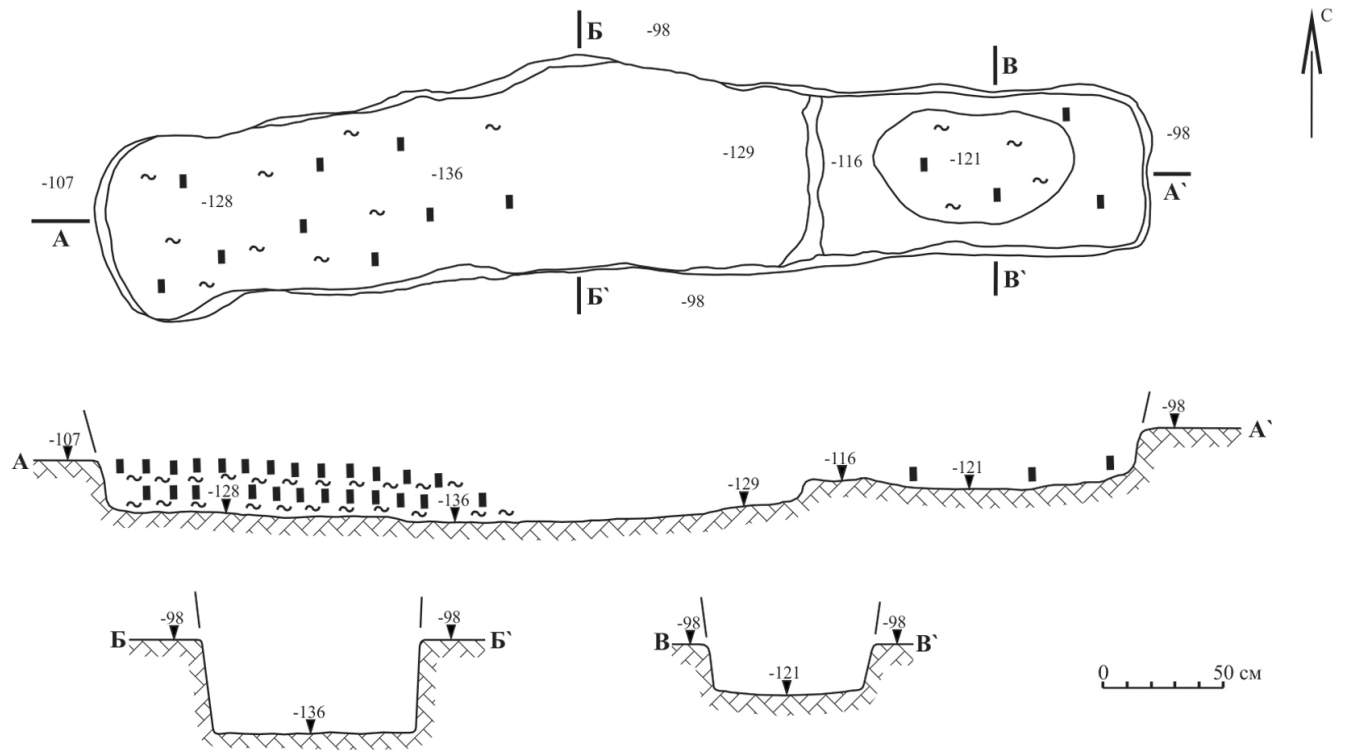

2.

Рис. 6. Курганная группа № 46 у хут. Ханьков. Курган 2. Планы и профили ям:

1 - ямы 7 и $8 ; 2$ - яма 9

Fig. 6. Barrow group no. 46 near the Khankov village. Barrow 2. Plans and profiles of the pits:

$$
1 \text { - pits } 7 \text { and } 8 ; 2-\text { pit } 9
$$


Yu.Yu. Kargin. Cossack's Dugouts in the Burial Mound on the Kuban River Right
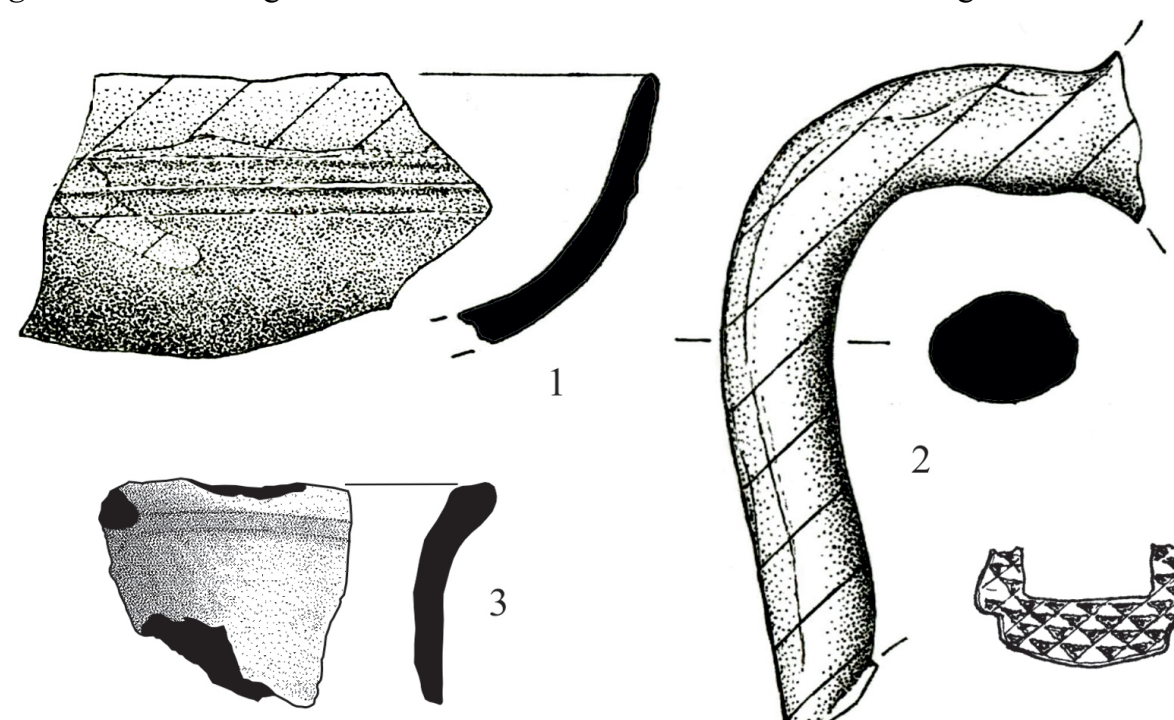

3


6
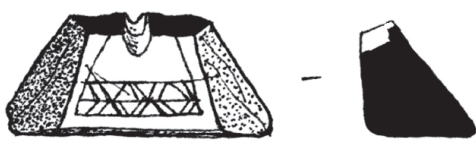

1



8
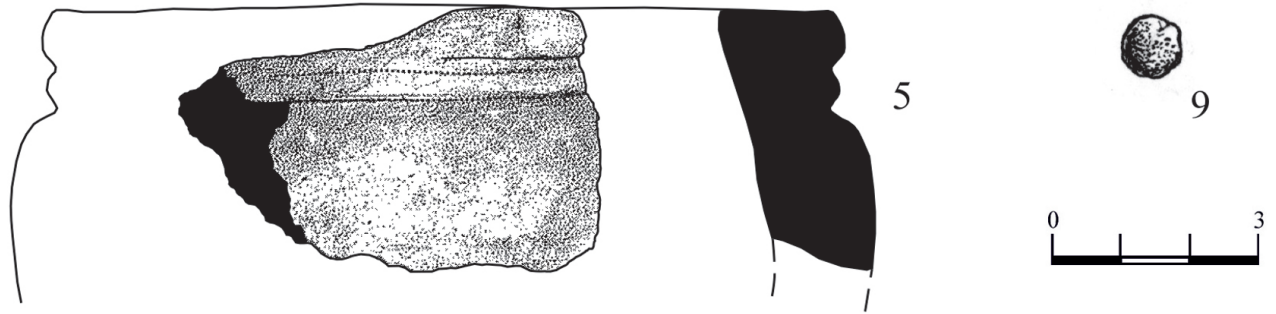

Рис. 7. Курганная группа № 46 у хут. Ханьков. Курган 2. Материалы XVIII в.:

1 - из насыпи; 2 - из печи $1 ; 3-4$ - из землянки $2 ; 5-7$ - из ямы $5 ; 8$ - из ямы $2 ; 9$ - из ямы 7 ;

1 - фрагмент верхней части поливной чаши «крымской группы»; 2 -ручка поливного кувшина «крымской» группы; 3 - фрагмент венчика неполивного кувшина «крымской группы»; 4-5 - фрагменты толстостенных горшков; 6 - кресальный кремень; 7 - фрагмент бронзовой пряжки; 8 - фрагмент орнаментированного изделия из кости; 9 - свинцовая сферическая пуля

Fig. 7. Barrow group no. 46 near the Khankov village. Barrow 2 . Materials of the $18^{\text {th }}$ century:

1 - from the mound; 2 - from the stove $1 ; 3-4$ - from the dugout $2 ; 5-7$ - from the pit $5 ; 8$ - from the pit 2; 9 - from the pit 7; 1 - top part of glazed bowl of "Crimean group"; 2 - a handle of the glazed jug of "Crimean group";

3 - top part of unglazed jug of "Crimean group"; $4-5$ - the parts of the thick-walled pots; 6 - aflint stone;

7 - a fragment of the bronze buckle; 8 - a fragment of the ornamented thing made of bone; 9 - a lead spherical bullet 
Ю.Ю. Каргин. Казачьи землянки в кургане на правобережье Кубани

Костные остатки животных в ямах и землянках XVIII в.

Определения В.В. Соломахи

\begin{tabular}{|c|c|c|c|c|c|c|c|}
\hline $\begin{array}{c}\text { Место } \\
\text { находки }\end{array}$ & КРС & Свинья & Рыба & Птица & Н.ф.к.к.м.* & Н.ф.к.с.м.** & ВСЕГО \\
\hline Землянка 2 & 5 & 13 & 3 & - & 2 & 1 & 24 \\
\hline Яма 2 & - & 2 & 3 & - & - & 1 & 6 \\
\hline Яма 4 & 5 & 12 & 12 & - & - & 6 & 35 \\
\hline Яма 5 & 1 & 21 & 27 & - & - & 4 & 53 \\
\hline Яма 7 & 1 & 2 & 8 & - & 2 & 1 & 14 \\
\hline Яма 8 & - & 1 & 2 & 2 & - & 1 & 6 \\
\hline ИТОГО & 12 & 51 & 52 & 2 & 4 & 14 & 135 \\
\hline$\%$ & 8,9 & 37,8 & 38,5 & 1,5 & 2,9 & 10,4 & 100 \\
\hline
\end{tabular}

Примечания. * - Н.ф.к.к.м. - неопределимые фрагменты костей крупных млекопитающих; ** - Н.ф.к.с.м. неопределимые фрагменты костей средних млекопитающих. 
Yu.Yu. Kargin. Cossack's Dugouts in the Burial Mound on the Kuban River Right

\section{ПРИМЕЧАНИЕ}

${ }^{1}$ Автор выражает благодарность А.А. Козорезову за возможность использовать материалы раскопок в публикации [Козорезов, 2016].

\section{СПИСОК ЛИТЕРАТУРЫ}

Антипина Е. Е., 2004. Археозоологические исследования: задачи, потенциальные возможности и реальные результаты // Новейшие археозоологические исследования в России. К столетию со дня рождения В.И. Цалкина. М. : Языки славянской культуры. С. 7-19.

Белов М. А., Лукьяшко С. И., Раев Б. А., 2015. Особенности планировки пастушеских поселений нового времени на Тамани (по результатам раскопок аула Тереклыкой) // Крым в войнах России : материалы Всерос. науч. конф. Ростов н/Д : Изд-во ЮНЦ РАН. С. 26-31.

Волков И. В., 1992. Керамика Азова XIV-XVIII вв. (Классификация и датировка) : автореф. дис. ... канд. ист. наук. М. 24 с.

Волков И. В., 2005. Крепость Лютик - Сед-Ислам (предварительное сообщение и керамический комплекс) // Поливная керамика Средиземноморья и Причерноморья X-XVIII вв. Т. 1. Киев : Изд. дом «Стилос». С. 482-492.

Волков И. В., Петерс Б. Г., 2003. Средневековый керамический комплекс поселения Гаркуша // Материалы и исследования по археологии Кубани. Вып. 3. Краснодар : Изд-во КубГУ. C. 244-261.

Даль В. В., 1981. Толковый словарь живого великорусского языка. Т. 2. М. : Русский язык. 700 с.

Данилевский Н. Я., 1871. Исследования о состоянии рыболовства в России. T. VIII : Описание рыболовства на Черном и Азовском морях (с атласом чертежей и рисунков). СПб. $316 \mathrm{c}$.

Двуреченский О. В., 2005. Боеприпас для ручного огнестрельного оружия Московской Руси конца XV - начала XVIII века // Археология Подмосковья : материалы научного семинара. Вып. 2. М. : ИА РАН. С. 264-295.

Каргин Ю. Ю., 2013а. Технический отчет о проведении научно-исследовательских археологических работ (раскопок) на объекте культурного наследия (памятнике археологии) Поселение «Ханьков II» (2900 кв. м), по титулу: «УЗРГ Анастасиевский с газопроводом-отводом» в Славянском районе Краснодарского края // Архив Управления государственной охраны объектов культурного наследия Краснодарского края. Отчеты, № 1136.
Каргин Ю. Ю., 2013б. Технический отчет о проведении научно-исследовательских археологических работ (раскопок) на объекте культурного наследия (памятнике археологии) Поселение «Ханьков II» (700 кв. м), по титулу: «УЗРГ Анастасиевский с газопроводом-отводом» в Славянском районе Краснодарского края // Архив Управления государственной охраны объектов культурного наследия Краснодарского края. Отчеты, № 1235.

Каргин Ю. Ю., 2016. Казаки-некрасовцы на правобережье Старой Кубани (по материалам охранных раскопок поселения Белое Юго-Восточное в 2014 г.) // Материалы по археологии и истории античного и средневекового Крыма. Вып. 8. Севастополь ; Тюмень ; Нижневартовск. С. 93-191

Когитин В. В., Рыблова М. А., 1995. Эволюция традиционного жилища донских казаков // Проблемы истории казачества. Волгоград : Изд-во ВолГУ.

Козорезов А. А., 2016. Отчет об археологических исследованиях курганов № 2 и 3 курганной группы № 46 и кургана № 48 у х. Ханьков Славянского района Краснодарского края в 2013 г. Ростов н/Д // Архив ИА РАН. Р-1. № 50145, 50146.

Куманцов М. И., 2011. Возникновение и развитие рыболовства Северного Причерноморья. Ч. 1 : От древности до начала XX в. М. : Изд-во ВНИРО.

Материалы этнографической экспедиции ВолГУ (МЭЭ ВолГУ), 1983. Волгоград. Ч. 27.

Материалы этнографической экспедиции ВолГУ (МЭЭ ВолГУ), 1987. Волгоград.

Сень Д. В., 2002. «Войско кубанское игнатово кавказское»: исторические пути казаков-некрасовцев (1708 г. - конец 1920-х гг.). Краснодар : Кубанькино. 286 с.

\section{REFERENCES}

Antipina E.E., 2004. The archaeozoological investigations: the tasks, potential capabilities and real results. Latest archaeozoological studies in Russia. To the $100^{\text {th }}$ birth anniversary of V.I. Tsalkin. Moscow, Yazyki slavyanskoy kultury Publ., pp. 7-19. (in Russian).

Belov M.A., Lukyashko S.I., Raev B.A., 2015. Specific planning features of pastoral settlements on the Taman (according to the results of excavations in the aul of Tereklykoy). Crimea in Russian wars: Proceedings of the All-Russian Scientific Conference. Rostov-on-Don, Izd-vo YuNTs RAN, pp. 26-31. (in Russian). 
Volkov I.V., 1992. The ceramics from Azov of the $14^{\text {th }}$ $18^{\text {th }}$ centuries (classification and dating). Cand. hist. sci. abs. diss. Moscow. 24 p. (in Russian).

Volkov I.V., 2005. The Lyutik - Sed-Islam fortress (preliminary message and ceramics complex). Irrigation ceramics of the Mediterranean and the Black Sea region of the $10^{\text {th }}-18^{\text {th }}$ centuries. Vol. I. Kiev, Stilos Publ., pp. 482-492. (in Russian).

Volkov I.V., Peters B.G., 2003. The medieval ceramics complex from the Garkusha settlement. Materials and research on the archaeology of Kuban, iss. 3. Krasnodar, Izd-vo KubGU, pp. 244-261. (in Russian).

Dal V.V., 1981. The explanatory dictionary of the living Great Russian Language. Vol. 2. Moscow, Russkiy yazyk Publ. 700 p. (in Russian).

Danilevskiy N.Ya., 1871. The investigations about the fishing in Russia. Vol. VIII: The description of the fishing on the Black and Azov seas (with the atlas of drawings and figures). Saint Petersburg. 316 p. (in Russian).

Dvurechenskiy O.V., 2005. The Moscow's Russian handgun's ammunition from the end of the $15^{\text {th }}$ to the beginning of the $18^{\text {th }}$ centuries. The archaeology of the Moscowregion: proceedings of academic seminar, iss. 2. Moscow, Izd-vo IA RAN, pp. 264-295. (in Russian).

Kargin Yu.Yu., 2013a. The technical report on archaeological excavations of the cultural heritage object (archaeological monument) Khankov settlement $\left(2900 \mathrm{~m}^{2}\right)$ by title: "GFMU Anastasievsky with gas pipeline" in the Slavyansk district of the Krasnodar region. Archive of Department of state protection of cultural heritage objects of the Krasnodar region, report no. 1136. (in Russian).

Kargin Yu.Yu., 2013b. The technical report on archaeological excavations of the cultural heritage object (archaeological monument) Khankov settlement $\left(700 \mathrm{~m}^{2}\right)$ by title: "GFMU Anastasievsky with gas pipeline" in the Slavyansk district of the Krasnodar region. Archive of Department of state protection of cultural heritage objects of the Krasnodar region, report no. 1235. (in Russian).

Kargin Yu.Yu., 2016. Nekrasov-Cossacks on the Old Kuban river right bank (based on security excavations of "South-East Beloye" settlement in 2014). Materials on archaeology and history of antique and medieval Crimea. Iss. 8. Sevastopol; Tyumen; Nizhnevartovsk, pp. 93191. (in Russian).

Kogitin V.V., Ryblova M.A., 1995. The evolution of Don Cossacks' traditional housing. Issues of Cossacks' history. Volgograd, Izd-vo VolGU (in Russian).

Kozorezov A.A., 2016. The report on excavations of burial mounds no. 2 and no. 3 of the burial group no. 46 and burial mound no. 48 near Khankov settlement of Slavyansk district of the Krasnodar region in 2013, Rostov-on-Don. Archive of IA RAS, R. 1, no. 50145, 50146.

Kumantsov M.I., 2011. The emergence and the development of fishing industry in the Black Sea region. Part 1: From the antiquity to the beginning of the $20^{\text {th }}$ century. Moscow, Izd-vo VNIRO. (in Russian).

The materials of VolSU ethnographic expedition, 1983. Volgograd. Part 27. (in Russian).

The materials of VolSU ethnographic expedition, 1987. Volgograd. (in Russian).

Sen D.V., 2002. The Caucasian Kuban army of Ignat: the historical ways of Nekrasov-Cossaks (1708-the end of 1920s). Krasnodar, Kubankino Publ. 286 p. (in Russian).

\section{Information about the Author}

Yuriy Yu. Kargin, Candidate of Sciences (History), Head of Scientific Service at Arkheologicheskaya ekspeditsiya Ltd., Kolkhozny Lane, 11, 346580 Rodionovo-Nesvetayskaya vill., Rostov-on-Don Region, Russian Federation, karginyy@mail.ru.

\section{Информация об авторе}

Юрий Юрьевич Каргин, кандидат исторических наук, начальник научной службы ООО «Археологическая экспедиция», пер. Колхозный, 11, 346580 сл. Родионово-Несветайская, Ростовская область, Российская Федерация, karginyy@mail.ru. 